\title{
AN INVESTIGATION OF ENTREPRENEURIAL INTENTION AMONG ENTREPRENEURSHIP STUDENTS IN SOUTH-WEST NIGERIA POLYTECHNICS
}

\author{
BAKO, Y.A. ${ }^{l}$ AJIBODE, I.A. ${ }^{2}$, OLUSEYE A.B. ${ }^{3} \&$ ALADELUSI K. B. ${ }^{4}$ \\ Federal Polytechnic, Ilaro, Ogun State, Nigeria
}

\begin{abstract}
This study was undertaken to explore the entrepreneurial intention of Polytechnic Students in Nigeria with case study of the Federal Polytechnic Ilaro. The population for the study was all students from various department undergoing entrepreneurship education/training in the polytechnics in south-west Nigeria. The sample size for the study is 3000 respondents. The respondent were selected by using simple random sampling. Logistic regression model was used for the hypothesis tested. The two environmental factors examined were Family environment and Nigeria environment. The impact/significant of these factors were examined to know how they can impact on students entrepreneurship intention. The study revealed that parental entrepreneurship skill directly influence students' entrepreneurial intention and that opportunities that exist in Nigeria affect students' entrepreneurial intention. Hence, the researcher suggest that schools should involve the services of psychologist and motivational speakers in Nigeria entrepreneurship curriculum in order to work on the students' reasoning mentality about entrepreneurship.
\end{abstract}

\section{KEYWORDS}

Entrepreneurship, Intention, Education, Polytechnic

\section{INTRODUCTION}

The history of entrepreneurship education can be dated back to 1938 while Shigeru Fijii, who turned into the teaching pioneer at Kobe University, japan had initiated schooling in entrepreneurship (Alberti, 2004). Notwithstanding the maximum of the entrepreneurship guides and programs had been pioneered and added in American universities. Many American universities has relatively long lifestyle as entrepreneurship training providers through its business colleges and have well documented entrepreneurship courses, paving the manner for entrepreneurship research as a legitimate area of educational programs (Franke and Luthje, 2004; Raichaudhuri, 2005). Entrepreneurship education, according to Binks (2005), refers back to the pedagogical manner concerned inside the encouragement of entrepreneurial activities behaviours and mindsets. Feature of entrepreneurship training has been lauded as being capable to create and increase awareness as well as promote self-employment as a profession desired amongst young people (Clayton 1989; Fleming 1996). Therefore the position of entrepreneurship training is to build an entrepreneurial

\footnotetext{
${ }^{1}$ Corresponding address: Business Administration Department, Federal Polytechnic, Ilaro, Ogun State, Nigeria.

${ }^{2}$ Corresponding address: Department of Mathematics and Statistics, Federal Polytechnic, Ilaro, Ogun State, Nigeria.

Email: ileloveseun@yahoo.com

${ }^{3}$ Corresponding address: Department of General studies, Federal Polytechnic, Ilaro, Ogun State, Nigeria.

${ }^{4}$ Corresponding address: Department of Banking and Finance, Federal Polytechnic, Ilaro, Ogun State, Nigeria.
} 
culture among young humans that, in flip, could improve their career picks towards entrepreneurship (Deakins, and Glancey 2005).

In other phrases, the targets of entrepreneurship education are aimed in converting students' state of behaviours and even goals that makes them to apprehend entrepreneurship, to turn out to be entrepreneurial and to grow to be an entrepreneur that in the end results in the formation of new organizations in addition to new process possibilities (Fayolle and Gailly 2005; Hannon 2005; Venkatachalam and Waqif 2005). In reaching this, the design of entrepreneurship training curriculum want to be innovative and creative and most significantly is 'tying academic getting to know to the real global' (Robinson and Haynes, 1991). Studies have been considerably centered on the sector of entrepreneurship schooling, which has enjoyed exponential boom degree internationally (Hill and Cinneide 2003; Raichaudhuri 2005). That is evident from the strands of studies which have been carried out on the ability of entrepreneurship to create new jobs and the importance of entrepreneurship training in generating capacity entrepreneurs from the instructional machine (Kuratko, 2005; Venkatachalam and Waqif 2005). For instance, Volery and Mueller (2006) spotlight the opportunity of the position of entrepreneurship education in influencing a character's selection to become an entrepreneur. Participation in entrepreneurship education, in this regard, has been related to the growing interest towards deciding on entrepreneurship as a feasible career option (Gorman and Hanlon, 1997).

To this end, Universities and different institutions were given the mandate to play a leading function in inculcating students with the entrepreneurial knowledge and capabilities so as to be useful in their destiny profession endeavours (Nurmi and Paasio, 2007). Entrepreneurship schooling has been identified as one of the critical determinants that might have an effect on college students' profession decisions (Kolvereid and Moen, 1997; Peterman and Kennedy, 2003). Due to that effect, there may be a want to take a look at how entrepreneurship education should have an impact on polytechnic college students' propensity to entrepreneurship. notwithstanding the exponential growing research interest in the location of entrepreneurship training (Wong and Lena, 2005; Menzies and Tatroff, 2006), as some distance as the researchers is aware, very little research has been particularly investigated the relationship among entrepreneurship training and entrepreneurial inclination particularly on Nigerian tertiary establishments students.

Edwards and Muir (2005) opined that entrepreneurial curriculum develops otherwise across universities, both as a non-obligatory module inside commercial enterprise publications or a selected guides on entrepreneurship. Levie (1999) in his observation on entrepreneurship training in England found that entrepreneurship coaching and guides are commonly categorized into two strategies: publications for entrepreneurship and guides approximately entrepreneurship. The decisions on teaching methodologies in entrepreneurship courses are therefore influenced with the aid of the intention of the academic goal.

Entrepreneurship schooling keeps attracting interest from each public, private sectors with the commitment from both academicians and coverage makers. This is why the ministry of education has made it compulsory for Universities, Polytechnics and colleges of education to include entrepreneurship education in their numerous curricula.

\section{STATEMENT OF THE PROBLEM}

The impact of entrepreneurship education is yet to be felt on Nigeria's economy, hence there is a serious and urgent need to access the impact of such entrepreneurship education on entrepreneurial intention among students. Also, there is need to investigate such factors that can ignite entrepreneurial intention among students so that relevant facilities will be put in place. 
It is observed that the family members did not encourage their wards to engage in entrepreneurship. This is not good for entrepreneurial intentions.

For long the Nigeria environment expects their educated young children to seek for paid employment in corporation's government parastatals or civil service. This is an indication that the society does not support the entrepreneurial intentions of graduates about to enter into world of work.

Another factor that may account for variation in students' entrepreneurial intention is situational factors which simply means perceived unemployment after graduation and family commitments on entrepreneurial intentions. It is a worrying situation in Nigeria to note that there are various environmental factors militating against student's intention to be entrepreneur.

Since the introduction of entrepreneurship education in schools; colleges, polytechnic and universities, for continuous effort to encourage young graduates to have entrepreneurial skills and initiatives; it requires acquisition of knowledge, skills, attitudes and in making sure that the skills acquired are well utilized for progress, create employments which will at long run transform the economy. This skills appears not to be well utilized.

\section{OBJECTIVES}

The main objectives of this study are:

- To determine the influence of perceived support and barriers on students' entrepreneurial intention.

- To determine the extent to which locus of control contribute to students' entrepreneurial intention.

- To determine the extent to which need for achievement contribute to students' entrepreneurial intention.

- To determine whether students has entrepreneurial intention to own a company.

- To determine the extent which instrumental readiness contribute to the students' entrepreneurial intention.

- To examine how subjective norms contribute to students' entrepreneurial intention.

\section{RESEARCH METHODOLOGY}

\section{A. POPULATION AND SAMPLE OF THE STUDY}

The target population for this study was Polytechnic students in South-West Nigeria. South-West Nigeria is one of the six geo-political zones of Nigeria. It comprise Ogun State, Lagos State, Osun State, Ekiti State, Oyo State and Ondo States. The population of the study is, therefore, all the ND II and HND II Students offering entrepreneurship course in all the Polytechnics in the six States. The choice of South-West geo-political zone is informed by the fact that the researchers have been living and working in one of the States (Ogun) for the past ten years on the average. More also, entrepreneurship education has being introduce in to tertiary institutions in the South-West for about ten years.

Six of the government owned Polytechnics in the South-West were randomly selected for the survey. This selection was done in such a way that one Polytechnic emerged from each of the states. Also, in each of the six Polytechnics, sampling frame of entrepreneurship students were obtained 
and $20 \%$ of the counted student population were selected for the study using simple random sampling techniques. Therefore the sample size for this study is 3000 students.

\section{B. DATA COLLECTION}

Data were collected by using a structured questionnaire adopted form Salwah, Siti and Norhatta (2015) on factors affecting entrepreneurial intention which comprised of the following sections; that is, personal details of the respondents, past experience, family background, entrepreneurial intention, attitude towards entrepreneurships, perceived support and barriers, locus of control, need for achievement, instrumental readiness and subjective norms.

\section{DATA ANALYSIS}

The descriptive statistics, frequencies and percentages and tabulation techniques were used to describe the profile information of the study. However, in order to achieve the objectives of the study, binary logistic regression model was used because of the dichotomous nature of the dependent variable.

In Logistic regression model the expected value of $\mathrm{Y}$ is conditional to $\mathrm{X}$, but not a linear relationship; this implies the residue cannot be normally distributed. The dependent variable is qualitative with two value ( 1 for an intention to be an entrepreneur or 0 otherwise).

$\log \left[\frac{p_{i}}{1-p_{i}}\right]=\beta_{0}+\beta_{1} x_{i 1}+\beta_{2} x_{i 2}+\ldots+\beta_{k} x_{i k}$

Where, $p_{i}=P\left(Y_{i}=1\right)$ $\ldots 1$

$\operatorname{Pr}(Y=1)=\frac{1}{1+\exp \left[-\left(\beta_{f 0}+\beta_{1} X_{f 1}+\beta_{2} X_{f 2}+\ldots+\beta_{k} X_{f k}\right)\right]} \quad \ldots 3$

\section{RESULT AND DISCUSSION}

This section provides a brief account of the studied sample and the interpretation and discussion of the outputs of binary logistic regression model used.

\section{A. PROFILE OF THE SAMPLE}

The 3000 questionnaires were keyed in into SPSS version 20 for analysis. Table 1 shows the distribution of the students with respect to their response on their intention to own a business or not. The reliability of the questionnaire was examined using Cronbach's Alpha value of 0.854 . This indicates that the questionnaire is highly reliable.

Table 1: Distribution of the respondents with respect to schools

\begin{tabular}{|ll|r|r|r|r|r|r|r|r|}
\hline & & \multicolumn{9}{|c|}{ School } & \multicolumn{2}{c|}{ Total } \\
\cline { 3 - 9 } & & fpi & ibadan poly & yabatech & ede poly & ondopoly & osunpoly & adopoly \\
\hline I wish to have my own & No & 253 & 379 & 204 & 179 & 160 & 129 & 97 & 1401 \\
business & Yes & 357 & 435 & 233 & 194 & 146 & 135 & 99 & 1599 \\
Total & & 610 & 814 & 437 & 373 & 306 & 264 & 196 & 3000 \\
\hline
\end{tabular}


In all, 1401 students affirmed no on their intention to own a business representing $46.7 \%$ of the population as seeing in table 2, while the remaining 1599 out of the 3000 respondents affirmed yes representing $53 \%$ of the entire sample surveyed.

Table 2: Overall responses of respondents on their entrepreneurial intention

\begin{tabular}{|rl|r|r|r|r|}
\hline & Frequency & Percent & Valid Percent & \multicolumn{1}{c|}{$\begin{array}{c}\text { Cumulative } \\
\text { Percent }\end{array}$} \\
\hline \multirow{3}{*}{ Valid } & No & 1401 & 46.7 & 46.7 & 46.7 \\
& Yes & 1599 & 53.3 & 53.3 & 100.0 \\
& Total & 3000 & 100.0 & 100.0 & \\
\hline
\end{tabular}

\section{B. ENTREPRENEURIAL INTENTION}

$H_{O 1}$ : Perceived support and barriers does not significantly influenced students' intention to become an entrepreneur.

Goodness-of-fit statistics help to determine whether the model adequately describes the data as seen in table 3. The Hosmer and Lemeshow statistic indicates a good fit since the p-value is greater than 0.05 . Hence we can go ahead with the model specification and other tests.

Table 3: Hosmer and Lemeshow Test

\begin{tabular}{|l|r|r|r|}
\hline Step & Chi-square & df & \multicolumn{1}{c|}{ Sig. } \\
\hline 1 & 38.457 & & 8 \\
\hline
\end{tabular}

From table 4, Omnibus tests of model coefficients' chi-square value is statistically significant, since the p-value is less than 0.05 . This implies that there is significant improvement in the model when compared to the null model. Moreover, table 5 shows the explanatory capacity of the model varies from $2.3 \%$ to $3.0 \%$.

Table 4: Omnibus Tests of Model Coefficients

\begin{tabular}{|rl|r|r|r|}
\hline & & Chi-square & df & \multicolumn{1}{c|}{ Sig. } \\
\hline \multirow{3}{*}{ Step 1 } & Step & 68.854 & 6 & .000 \\
& Block & 68.854 & 6 & .000 \\
& Model & 68.854 & 6 & .000 \\
\hline
\end{tabular}

Table 5: Model Summary

\begin{tabular}{|l|r|r|r|}
\hline Step & -2 Log likelihood & $\begin{array}{c}\text { Cox \& Snell R } \\
\text { Square }\end{array}$ & $\begin{array}{c}\text { Nagelkerke R } \\
\text { Square }\end{array}$ \\
\hline 1 & $4076.952^{\mathrm{a}}$ & .023 & .030 \\
\hline
\end{tabular}

a. Estimation terminated at iteration number 3 because parameter estimates changed by less than .001 .

Table 6 is used for model specification and to test significant of any of the thirteen factors. The result indicates that six of the factors under the perceived support and barriers are statistically significant. This is an indication that students' intention to become an entrepreneur influenced by six factors on perceived support and barriers

$\mathrm{SEI}=1.602-0.205 \mathrm{PSB} 8+0.201 \mathrm{PSB} 10-0.158 \mathrm{PSB} 11-0.119 \mathrm{PSB} 13-0.160 \mathrm{PSB} 15-0.087 \mathrm{PSB} 33$

Where,

SEI stands for Students Entrepreneurial Intention

PSB8 stands for item 8 in the questionnaire on perceived support and barriers

PSB10 stands for item 10 in the questionnaire on perceived support and barriers

PSB11 stands for item 11 in the questionnaire on perceived support and barriers

PSB13 stands for item 13 in the questionnaire on perceived support and barriers 
PSB15 stands for item 15 in the questionnaire on perceived support and barriers PSB33 stands for item 33 in the questionnaire on perceived support and barriers

Table 6: Variables in the Equation

\begin{tabular}{|rl|r|r|r|r|r|r|}
\hline & \multicolumn{1}{|c|}{ B } & \multicolumn{1}{|c|}{ S.E. } & Wald & df & \multicolumn{1}{|c|}{ Sig. } & \multicolumn{1}{c|}{$\operatorname{Exp}(\mathrm{B})$} \\
\hline & PSB8 & -.205 & .050 & 16.960 & 1 & .000 & .815 \\
& PSB10 & .201 & .051 & 15.347 & 1 & .000 & 1.223 \\
& PSB11 & -.158 & .045 & 12.243 & 1 & .000 & .854 \\
Step 1 $^{\mathrm{a}}$ & -.119 & .046 & 6.805 & 1 & .009 & .888 \\
& PSB13 & -.160 & .041 & 15.302 & 1 & .000 & .852 \\
& PSB15 & -.087 & .038 & 5.318 & 1 & .021 & .916 \\
& PSB33 & 1.602 & .245 & 42.645 & 1 & .000 & 4.964 \\
\hline
\end{tabular}

a. Variable(s) entered on step 1: PSB8, PSB10, PSB11, PSB13, PSB15, PSB33

This result suggests that all the six factors are statistically significant with p-values less than 0.05 . However, except for PSB10 (item 10) in the questionnaire "my family encourages me to set up my own business" that has positive effect on entrepreneurial intention of the students with odds of 0.201 and this set of students are 1.223 times more likely to be an entrepreneur if all other things remain constant. But, other factors contribute negatively to their intention in becoming an entrepreneur with less probability.

\section{$H_{o 2}$ : Locus of control does not significantly influenced students intention to be an entrepreneur.}

The Hosmer and Lemeshow statistic (table 7) indicates a good fit since the p-value is greater than 0.05 ( $\mathrm{p}-0.245$ ). Hence we can go ahead with the model specification and other tests.

\section{Table 7: Hosmer and Lemeshow Test}

\begin{tabular}{|c|c|c|c|}
\hline Step & Chi-square & $\mathrm{df}$ & Sig. \\
\hline 1 & 93.740 & 8 & .245 \\
\hline
\end{tabular}

From table 8, Omnibus tests of model coefficients', the Chi-square value is statistically significant ( $p$-value $=0.000)$ since the $p$-value is less than 0.05 . This implies that there is significant improvement in the model when compared to the null model. Moreover, table 9 shows the explanatory capacity of the model varies from $2.8 \%$ to $3.8 \%$.

Table 8: Omnibus Tests of Model Coefficients

\begin{tabular}{|rl|r|r|r|}
\hline & & Chi-square & df & \multicolumn{1}{c|}{ Sig. } \\
\hline \multirow{3}{*}{ Step 1 } & Step & 85.711 & 4 & .000 \\
& Block & 85.711 & 4 & .000 \\
& Model & 85.711 & & .000 \\
\hline
\end{tabular}

Table 10 is used for model specification and to test significant of any of the twelve factors. The result indicates that only four of the factors under locust of control are statistically significant. This is an indication that students' intention to become an entrepreneur is influenced by the four factors under locus of control.

Table 9: Model Summary

\begin{tabular}{|l|r|r|r|}
\hline Step & -2 Log likelihood & $\begin{array}{c}\text { Cox \& Snell R } \\
\text { Square }\end{array}$ & $\begin{array}{c}\text { Nagelkerke R } \\
\text { Square }\end{array}$ \\
\hline 1 & $4060.095^{\mathrm{a}}$ & .028 & .038 \\
\hline
\end{tabular}


a. Estimation terminated at iteration number 3

because parameter estimates changed by less than .001 .

$\mathrm{SEI}=1.605-0.204 \mathrm{LC} 21-0.155 \mathrm{LC} 24+0.081 \mathrm{LC} 26-0.226 \mathrm{LC} 29$

Where,

LC21 stands for item 21 in the questionnaire on locus of control

LC24 stands for item 24 in the questionnaire on locus of control

LC26 stands for item 26 in the questionnaire on locus of control

LC29 stands for item 29 in the questionnaire on locus of control

Only four of the factors are statistically significant with p-values less than 0.05 . Items $21,24,26$ and 29 (when everything goes right, I think it is a question of luck, do you try new things, do you develop any strategy to detect opportunities and I am confident of my skills and abilities to start a business). Three of the factors contribute negatively with odds $-0.204,-0.155$ and -0.226 but item 26 (do you develop any strategy to detect opportunities) contributing positively with odd value of 0.081 and this sets of students that detect opportunities are 1.084 times more likely to be an entrepreneur if all other things remain constant. But, other factors contribute negatively to their intention in becoming an entrepreneur with high probability.

Table 10: Variables in the Equation

\begin{tabular}{|rl|r|r|r|r|r|r|}
\hline & \multicolumn{1}{|c|}{ B } & \multicolumn{1}{|c|}{ S.E. } & Wald & df & \multicolumn{1}{c|}{ Sig. } & \multicolumn{1}{c|}{$\operatorname{Exp(B)}$} \\
\hline \multirow{3}{*}{ Step 1a } & LC21 & -.204 & .039 & 26.797 & 1 & .000 & .816 \\
& LC24 & -.155 & .048 & 10.680 & 1 & .001 & .856 \\
& LC26 & .081 & .044 & 3.316 & 1 & .042 & 1.084 \\
& LC29 & -.226 & .046 & 24.578 & 1 & .000 & .797 \\
& Constant & 1.605 & .217 & 54.874 & 1 & .000 & 4.980 \\
\hline
\end{tabular}

a. Variable(s) entered on step 1: LC21, LC24, LC26, LC29

\section{$H_{O 3}$ : Need for achievement does not significantly influenced students intention to be an entrepreneur.}

The Hosmer and Lemeshow statistic indicates a good since the p-value of the analysis is 0.064 (table 11) which is greater than 0.05 . Here, the model adequately fits the data since the significance value $(p>0.05)$ is greater than 0.05 . Hence we can go ahead with the model specification and other tests.

Table 11: Hosmer and Lemeshow Test

\begin{tabular}{|l|r|r|r|}
\hline Step & Chi-square & df & \multicolumn{1}{|c|}{ Sig. } \\
\hline 1 & 94.654 & & 8 \\
\hline
\end{tabular}

From table 12, which is the tests of model specification, the Chi-square (122.603) shows that the model is significant with $(\mathrm{p}<0.05)$. Thus, it implies that there is a significant improvement in the model when compared with null model.

Table 12: Omnibus Tests of Model Coefficients

\begin{tabular}{|c|c|c|c|c|}
\hline & & Chi-square & $\mathrm{df}$ & Sig. \\
\hline \multirow{3}{*}{ Step 1} & Step & 122.603 & 5 & .000 \\
\hline & Block & 122.603 & 5 & .000 \\
\hline & Model & 122.603 & 5 & .000 \\
\hline
\end{tabular}

Table 13 shows the explanatory capacity of the model is $4 \%$ and $6.3 \%$ indicating that there is a very weak relationship between students' intention to be an entrepreneur and joint effect of factors on need for achievement. 
Table 13: Model Summary

\begin{tabular}{|l|r|r|r|}
\hline Step & -2 Log likelihood & $\begin{array}{c}\text { Cox \& Snell R } \\
\text { Square }\end{array}$ & $\begin{array}{c}\text { Nagelkerke R } \\
\text { Square }\end{array}$ \\
\hline 1 & $4023.203^{\mathrm{a}}$ & .040 & .053 \\
\hline
\end{tabular}

a. Estimation terminated at iteration number 3

because parameter estimates changed by less than .001 .

From table 14 showing the variables in the equation, only two of the factors; item 33 and 36 , are statistically significant with odds 0.149 and -0.450 . The result indicates that, most students that believe that they will do well in difficult task relating to their study and work are 1.161 times more likely to be an entrepreneur because this factor contributes positively to their entrepreneurial intention, however leadership skills that are needed to be an entrepreneur contributes negatively to their intention and this set of students has 0.638 chance of being an entrepreneur.

The model is:

$\mathrm{SEI}=1.152+0.149 \mathrm{NA} 33-0.042 \mathrm{NA} 34-0.045 \mathrm{NA} 35-0.450 \mathrm{NA} 36+0.057 \mathrm{NA} 37$

Where,

NA33 stands for item 33 in the questionnaire

NA34 stands for item 34 in the questionnaire

NA35 stands for item 35 in the questionnaire

NA36 stands for item 36 in the questionnaire

NA37 stands for item 37 in the questionnaire

Table 14: Variables in the Equation

\begin{tabular}{|rl|r|r|r|r|r|r|}
\hline & \multicolumn{1}{|c|}{ B } & \multicolumn{1}{|c|}{ S.E. } & \multicolumn{1}{c|}{ Wald } & \multicolumn{1}{c|}{ df } & \multicolumn{1}{c|}{ Sig. } & \multicolumn{1}{|c|}{$\operatorname{Exp}(\mathrm{B})$} \\
\hline & NA33 & .149 & .044 & 11.339 & 1 & .001 & 1.161 \\
& NA34 & -.042 & .051 & .687 & 1 & .407 & .959 \\
Step 1 & NA35 & -.045 & .051 & .780 & 1 & .377 & .956 \\
& NA36 & -.450 & .050 & 82.537 & 1 & .000 & .638 \\
& NA37 & .057 & .047 & 1.501 & 1 & .220 & 1.059 \\
& Constant & 1.152 & .190 & 36.578 & 1 & .000 & 3.164 \\
\hline
\end{tabular}

a. Variable(s) entered on step 1: NA33, NA34, NA35, NA36, NA37

\section{$H_{O 4}$ : Need to own a company does not significantly influenced students intention to be an entrepreneur.}

The Hosmer and Lemeshow statistic indicates a good fit of the model with significance value greater than 0.05 (Table 15). Hence we can go ahead with the model specification and other tests.

Table 15: Hosmer and Lemeshow Test

\begin{tabular}{|l|r|r|r|}
\hline Step & Chi-square & df & \multicolumn{1}{|c|}{ Sig. } \\
\hline 1 & 37.948 & & 8 \\
\hline
\end{tabular}

From table 16, the Omnibus tests of model coefficients' Chi-square value is (82.021) with significant value less than $0.05(\mathrm{p}$-value $=0.000)$. This indicates significant improvement in the model when compared to the null model.

Table 16: Omnibus Tests of Model Coefficients

\begin{tabular}{|rl|r|r|r|}
\hline & & Chi-square & df & \multicolumn{1}{|c|}{ Sig. } \\
\hline \multirow{3}{*}{ Step 1 } & Step & 82.021 & 3 & .000 \\
& Block & 82.021 & 3 & .000 \\
& Model & 82.021 & 3 & .000 \\
\hline
\end{tabular}


Moreover, table 17 shows the explanatory capacity of the model varies from $2.7 \%$ to $3.6 \%$ with loglikelihood value of 4063.784.

Table 17: Model Summary

\begin{tabular}{|l|r|r|r|}
\hline Step & -2 Log likelihood & $\begin{array}{c}\text { Cox \& Snell R } \\
\text { Square }\end{array}$ & $\begin{array}{c}\text { Nagelkerke R } \\
\text { Square }\end{array}$ \\
\hline 1 & $4063.784^{\mathrm{a}}$ & .027 & .036 \\
\hline
\end{tabular}

a. Estimation terminated at iteration number 3 because parameter estimates changed by less than .001 .

The results suggests that there is a very weak relationship between students' intention to be an entrepreneur and joint effect of factors on ownership of a company. However, out of the nine items used to test the hypothesis, only three of them are statistically significant.

Table 18: Variables in the Equation

\begin{tabular}{|rl|r|r|r|r|r|r|}
\hline & \multicolumn{1}{|c|}{ B } & \multicolumn{1}{|c|}{ S.E. } & Wald & df & \multicolumn{1}{c|}{ Sig. } & \multicolumn{1}{c|}{$\operatorname{Exp}(\mathrm{B})$} \\
\hline \multirow{3}{*}{ Step 1a } & EI40 & -.240 & .047 & 26.365 & 1 & .000 & .787 \\
& EI43 & .148 & .045 & 10.811 & 1 & .001 & 1.160 \\
& EI45 & -.272 & .048 & 31.785 & 1 & .000 & .762 \\
& Constant & 1.196 & .183 & 42.561 & 1 & .000 & 3.306 \\
\hline
\end{tabular}

a. Variable(s) entered on step 1: EI40, EI43, EI45.

$\mathrm{SEI}=1.196-0.240 \mathrm{EI} 40+0.148 \mathrm{EI} 43-0.272 \mathrm{EI} 45$

Where,

EI40 is item 40 in the questionnaire

EI43 is item 43 in the questionnaire

EI45 is item 45 in the questionnaire

From table 18, item 40 preference to own a company has negative effect on students' entrepreneurial intention with odd value of -0.240 . Also, item 45 which is creation of new job has negative effect with odd -0.272 . The two items has probability 0.787 and 0.762 respectively.

Moreover, item 43 which is on freedom to express themselves in their business contributes positively with odd of 0.148 and this set of students are 1.160 times likely to be an entrepreneur.

\section{$H_{o 5}$ : Instrumental readiness does not significantly influenced students intention to be an entrepreneur.}

The Hosmer and Lemeshow statistic indicates a good fit with significance value greater than 0.05 (table 19). Here, the model adequately fits the data since the significance value $($ Sig. $=0.0 .91)$ is greater than 0.05 . Hence we can go ahead with the model specification and other tests.

\section{Table 19: Hosmer and Lemeshow Test}

\begin{tabular}{|l|r|r|r|}
\hline Step & Chi-square & df & Sig. \\
\hline 1 & 13.652 & & \\
\hline
\end{tabular}

From the Omnibus test of model coefficients in table 20, the Chi-square value (37.838) is significant as p-value is 0.000 which is less than $5 \%$ significant level.

Table 20: Omnibus Tests of Model Coefficients

\begin{tabular}{|rl|r|r|rr|}
\hline & & Chi-square & df & \multicolumn{2}{|c|}{ Sig. } \\
\hline \multirow{3}{*}{ Step 1 } & Step & 37.838 & 3 & & .000 \\
& Block & 37.838 & 3 & .000 \\
& Model & 37.838 & 3 & .000 \\
\hline
\end{tabular}


From table 21, the result of Cox \& Snell R square which is 0.013 and Nagelkerke R square which is 0.017 ; this implies that the explanatory capacity of the model varied between $1.3 \%$ and $1.7 \%$. The results indicates that there is a very weak relationship between students' intention to be an entrepreneur and joint effect of factors on instrumental readiness.

Table 21: Model Summary

\begin{tabular}{|l|r|r|r|}
\hline Step & -2 Log likelihood & $\begin{array}{c}\text { Cox \& Snell R } \\
\text { Square }\end{array}$ & $\begin{array}{c}\text { Nagelkerke R } \\
\text { Square }\end{array}$ \\
\hline 1 & $4107.968^{\mathrm{a}}$ & .013 & .017 \\
\hline
\end{tabular}

a. Estimation terminated at iteration number 3 because parameter estimates changed by less than .001 .

Table 18 shows model specification and to test significant of any of the three factors. Similar results were obtained as none of the factors under instrumental readiness is significant.

Table 22: Variables in the Equation

\begin{tabular}{|rl|r|r|r|r|r|r|}
\hline & \multicolumn{1}{|c|}{ B } & \multicolumn{1}{|c|}{ S.E. } & Wald & df & \multicolumn{1}{|c|}{ Sig. } & \multicolumn{1}{|c|}{$\operatorname{Exp(B)}$} \\
\hline \multirow{4}{*}{ Step 1 $1^{\text {a }}$} & IR47 & -.116 & .038 & 9.124 & 1 & .003 & .891 \\
& IR48 & -.122 & .046 & 6.979 & 1 & .008 & .885 \\
& IR49 & -.104 & .047 & 4.895 & 1 & .027 & .902 \\
& Constant & 1.105 & .165 & 44.861 & 1 & .000 & 3.018 \\
\hline
\end{tabular}

a. Variable(s) entered on step 1: IR47, IR48, IR49.

The model,

$\mathrm{SEI}=1.105-0.116 \mathrm{IR} 47-0.122 \mathrm{IR} 48-0.104 \mathrm{IR} 49$

Where,

IR47 stands for item 47 in the questionnaire

IR48 stands for item 48 in the questionnaire

IR49 stands for item 49 in the questionnaire

Here all the variables on instrumental readiness are significant with odds of $-0.116,-0.122$ and 0.104 with p-values $0.003,0.008$ and 0.027 . Items on instrumental readiness are; access to capital to start up as an entrepreneur, access to social networks that can be utilized for entrepreneurial decision and access to supporting information to start up a business. Students' are 0.891 times likely to be an entrepreneur with item 47 holding other factors constant, 0.885 times likely to be an entrepreneur with item 48 holding other factors constant and 0.902 times likely to be an entrepreneur with item 49 holding other factors constant.

\section{$H_{O 6}:$ Students' subjective norms does not significantly influenced students' intention to be an entrepreneur.}

From the Hosmer and Lemeshow statistic in table 23, indicates a good fit since the significance value is greater than $0.05(\mathrm{p}$-value $=0.078)$. Hence, the model adequately fits the data we proceed with the model specification and other tests.

Table 23: Hosmer and Lemeshow Test

\begin{tabular}{|c|c|c|c|}
\hline Step & Chi-square & $\mathrm{df}$ & Sig. \\
\hline 1 & 99.161 & 7 & .078 \\
\hline
\end{tabular}


The Omnibus test of model coefficients in table 24, the Chi-square value (22.994) is significant as p-value is 0.000 which is less than $5 \%$ significant level. Thus, it implies that there is significant improvement in the model when compared to the null model.

Table 24: Omnibus Tests of Model Coefficients

\begin{tabular}{|rl|r|r|r|}
\hline & & Chi-square & df & \multicolumn{2}{|c|}{ Sig. } \\
\hline \multirow{3}{*}{ Step 1 } & Step & 22.994 & 3 & .000 \\
& Block & 22.994 & 3 & .000 \\
& Model & 22.994 & 3 & .000 \\
\hline
\end{tabular}

From table 25, the result of Cox \& Snell $\mathrm{R}$ square which is $0.8 \%$ and Nagelkerke $\mathrm{R}$ square which is 1.0 , the results indicates that there is a weak relationship between students' intention to be an entrepreneur and joint effect of factors on subjective norms.

Table 25: Model Summary

\begin{tabular}{|l|r|r|r|}
\hline Step & -2 Log likelihood & $\begin{array}{c}\text { Cox \& Snell R } \\
\text { Square }\end{array}$ & $\begin{array}{c}\text { Nagelkerke R } \\
\text { Square }\end{array}$ \\
\hline 1 & $4122.812^{\mathrm{a}}$ & .008 & .010 \\
\hline
\end{tabular}

a. Estimation terminated at iteration number 3

because parameter estimates changed by less than .001 .

Table 26, is used for model specification and to test significant of any of the three factors. Only two of the three factors are statistically significant. Item 50 which is on students belief on their leadership skills that are needed to be an entrepreneur contributes positively and has an odd of 0.160 with these sets of students having 1.174 times likely to start their own business. While item 51 , on mental maturity to start a business contributes negatively and has an odd of -0.215 with such students having 0.807 times likely to be an entrepreneur with other factors being constant. This indicates that these sets of students despite their leadership ability in being an entrepreneur still have doubt about their ability.

The model,

$\mathrm{SIE}=0.300+0.160 \mathrm{SN} 50-0.215 \mathrm{SN} 51-0.002 \mathrm{SN} 52$

Where,

SN50 stands for item 50 in the questionnaire

SN51 stands for item 51 in the questionnaire

SN52 stands for item 52 in the questionnaire

Table 26: Variables in the Equation

\begin{tabular}{|c|c|c|c|c|c|c|c|}
\hline & & B & S.E. & Wald & df & Sig. & $\operatorname{Exp}(B)$ \\
\hline \multirow{4}{*}{ Step $1^{a}$} & SN50 & . 160 & .049 & 10.571 & 1 & . 001 & 1.174 \\
\hline & SN51 & -.215 & .051 & 18.089 & 1 & .000 & .807 \\
\hline & SN52 & -.002 & .046 & .001 & 1 & .972 & .998 \\
\hline & Constant & .300 & .151 & 3.923 & 1 & .048 & 1.350 \\
\hline
\end{tabular}

a. Variable(s) entered on step 1: SN50, SN51, SN52.

\section{CONCLUSION/RECOMMENDATION}

This research work examined critically entrepreneurship intention among students in the Polytechnic with reference to Family and Nigeria Environmental Factors. It is clearly seen that parental guide is highly needed to increase the students' interest for entrepreneurship and also the opportunity that is clearly available in Nigeria contributes negatively to students' entrepreneurial 
intention. This suggests that most opportunities in the Nigerian business environment is not commensurate with the required enabling infrastructure needed by emerging entrepreneur. The findings suggest that students despite their entrepreneurial knowledge still have doubt about their ability to engage in entrepreneurship.

It is however recommended that enough motivational talk should be incorporated into entrepreneurship education in all our institutions so that the major purpose of this programme can be achieved. Because the programme as of today still seems not to have gotten to the desired level.

\section{SUGGESTION FOR FURTHER READING/STUDIES}

This research work further suggest a longitudinal research in order to measure students' entrepreneurial intention before and after entrepreneurship education in Nigeria tertiary institutions. However, it also suggest that there is need for ministry of education to have monitoring section to measure the level of achievement so far in this programme.

\section{ACKNOWLEDGEMENT}

The researchers acknowledge the support of Federal Polytechnic, Ilaro, Ogun State, Nigeria for the funding through Tertiary Education Trust Fund (TETFUND).

\section{REFERENCES}

Alberti, F. (2004). Entrepreneurship education: Note on an ongoing debate. 14th annual International Entrepreneurship Conference, University of Napoli Federico, Italy.

Béchard, J. P. \& Toulouse, J. M. (1998). "Validation of a didactic model for the analysis of training objectives in entrepreneurship." Journal of Business Venturing, 13, 317-332.

Binks, M. (2005). "Entrepreneurship education and integrative learning." Retrieved March 21, 2016, from http://www.ncge.org.uk/downloads/policy/Entrepreneurship_Education_and_Integrative_Lear ning.doc.

Charney, A. H. \& Libecap, G. D. (2003). "The contribution of entrepreneurship education: An analysis of the Berger programme". International Journal of Entrepreneurship Education, 1(3): $385-418$.

Clayton, G. (1989). "Entrepreneurship education at the postsecondary level." Retrieved March 20, 2016, from www.celcee.edu/abstracts/c19981683.html.

Cooper, S. \& Bottomley, C. (2004). "Stepping out of the classroom and up the ladder of learning: An experiential learning approach to entrepreneurship education." Industry \& Higher Education, 18(1), 11-22.

Deakins, D. \& Glancey, K. (2005). "Enterprise education: The role of Head Teachers." International Entrepreneurship and Management Journal, 1, 241-263.

Edwards, L. J. \& Muir, E. J. (2005). "Promoting entrepreneurship at the University of Glamorgan through formal and informal learning." Journal of Small Business and Enterprise Development, 12(4), 613-626.

Falkang, J. \& Alberti, F. (2000). "The assessment of entrepreneurship education." Industry \& Higher Education April, 101-108.

Fayolle, A. G. \& Gailly, B. (2005). Using the Theory of Planned Behaviour to assess entrepreneurship teaching programmes, Centre for Research in Change, Innovation and Strategy, 1-18. 
Fiet, J. O. (2000). "The theoretical side of teaching entrepreneurship." Journal of Business Venturing, 16, 1-24.

Fleming, P. (1996). "Entrepreneurship education in Ireland: A longitudinal study." Academy of Entrepreneurship Journal, 2(1), 95-119.

Franke, N. \& Luthje, C. (2004). "Entrepreneurship intentions of business students: A benchmarking study." $\quad$ Retrieved March 20, 2016, from www2.wuwien.ac.at/entrep/modules/UpDownload/store_folder/Publikationen/Nikolaus_Fran ke/entrepreneurialspirit.pdf.

Gorman, G. \& Hanlon, D. (1997). "Some research perspectives on entrepreneurship education, enterprise education and education for small business management: A ten-year literature review." International Small Business Journal, 15(3), 56-77.

Hagan, E. R. (2004). "Entrepreneurship education: A new frontier for American community colleges." Retrieved March 23, 2015, from www.celcee/org/ft/hagan dissertation final.pdf.

Hannon, P. D. (2005). The journey from student to entrepreneur: A review of the existing research into graduate entrepreneurship. UK, National Council for Graduate Entrepreneurship.

Hill, S. \& Cinneide, B. O. (2003). "Graduate entrepreneurship education: An internatinal "consumer" study." $\quad$ Retrieved March 18, 2016, from http://www.sbaer.uca.edu/Research/2003/ICSB/papers/5.doc.

Kent, C. A. (1990). Introduction: Educating the Heffalump. Entrepreneurship education: Current developments, future direction. A. K. Calvin. New York, USA, Quorum Books.

Kolvereid, L. \& Moen, O. (1997). "Entrepreneurship among business graduates: does a major in entrepreneurship make a different?" Journal of European Industrial Training, 21(4), 154-160.

Kourilsky, M. L. (1995). "Entrepreneurship education: Opportunity in search of curriculum." Retrieved March 22, 2016, from www.entreworld.org/Bookstore/PDFs/RE-008.pdf.

Kuratko, D. F. (2005). "The emergence of entrepreneurship education: Development, trends, and challenges". Entrepreneurship Theory and Practice September, 577-597.

Levie, J. (1999). Entrepreneurship education in higher education in England: A survey. UK, the Department for Employment and education.

Menzies, T. V. \& Tatroff, H.(2006). "The propensity of male vs. female students to take courses and degree concentrations in entrepreneurship." Journal of Small Business and Entrepreneurship, 19(2), 203-218.

Nurmi, P. \& Paasio, K. (2007). "Entrepreneurship in Finnish universities". Education + Training, 49(1), 56-65.

Peterman, N. E. \& Kennedy, J. (2003). "Enterprise education: influencing students'perceptions of entrepreneurship", Entrepreneurship Theory and Practice, 28(2), 129-144.

Raichaudhuri, A. (2005). "Issues in entrepreneurship education", Decision, 32(2), 73-84.

Robinson, P. \& Haynes, M. (1991). "Entrepreneurship education in America's major universities." Entrepreneurship Theory and Practice Spring: 41-52.

Salwah, C.M., Siti, M.M. \& Norhatta, M. (2015). Identifying factors that affecting the entrepreneurial intention among engineering technology students. $2^{\text {nd }}$ global conference on business and social science. September $17^{\text {th }}-18^{\text {th }}, 2015$, Bali, Indonesia.

Venkatachalam, V. B. \& Waqif, A. A. (2005). "Outlook on integrating entrepreneurship in management education in India". Decision, 32(2), 57-71.

Volery, T. \& Mueller, S. (2006). A conceptual framework for testing the effectiveness of entrepreneurship education programmes towards entrepreneurial intention. 51st ICSB World Conference Melbourne, Australia.

Wang, C. K. \& Wong, P. K. (2004). "Entrepreneurial interest of university students in Singapore." Technovation, 24(2), 163-172.

Wong, P. K. \& Lena, L. (2005). "Antecedents for entrepreneurial propensity in Singapore." Retrieved March 15, 2015, from http://unpanl.un.org/intradoc/groups/public/documents/APCITY/UNPAN023984.pdf. 
QUESTIONNAIRE ON ENTERPRENEURIAL INTENTION

CODE

The purpose of this Questionnaire is to assess your entrepreneurial intention and factors that would influence your intention. Work as quickly as you can and do not stop to think too deeply about the answers. Please answer all questions by TICKING the number which best represent your choice. Your cooperation is appreciated.

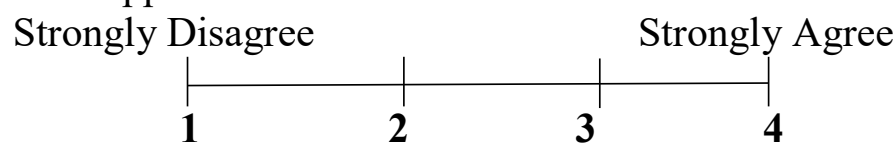

\section{PART A: PERSONAL DETAILS}

1. Age:

Below 18
$18-20$

21-23

Above 23

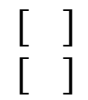

2. Gender:

Male

Female

3. Ethnic Group:

Yoruba

Igbo

Hausa

Others

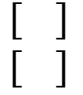

4. Religion:

Muslim

Christian

Others

5. The longest residing area:

$\begin{array}{lll}\text { City } & {[} & \text { Village } \\ \text { Town } & {[} & \end{array}$

6. Level:

ND

[ ] HND

7. Area of study:

Engineering

Management

Environmental

Science

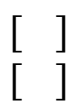

\section{PART B: PAST EXPERIENCE}

1. Do you have experience in the following area?
a. Sales experience
b. Supervisory role
c. Handling business account
d. Running some own businesses (excluding family businesses)
e. Running some businesses for others
i. Attended some formal class or workshop on entrepreneurship

\section{PART C: FAMILY BACKGROUND}

1. Father's highest education level

No formal education [ ] Primary [ ] Secondary [ ] Tertiary [ ]

2. Mother's highest education level

No formal education [ ] Primary [ ] Secondary [ ] Tertiary [ ]

3. Guardian's highest education level

No formal education [ ] Primary [ ] Secondary [ ] Tertiary [ ] 
4. Occupation/Profession of Father

Salary $\left[\begin{array}{l}\text { Non Salary } \\ \text { 5. [ ] }\end{array}\right.$ Occupation/Profession of Mother
Salary [ ] Non Salary [ ]

6. Occupation/Profession of Guardian

Salary [ ] Non Salary [ ] Retiree [ ]

\section{PART D: ENTERPRENEURIAL INTENTION}

- Please answer all questions

\# I wish to have my own business.

Yes [ ] No [ ]

\begin{tabular}{|c|c|c|c|c|}
\hline \multirow{2}{*}{ Questions } & \multicolumn{4}{|c|}{ Response } \\
\hline & \multirow[b]{2}{*}{ 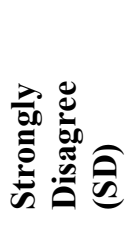 } & \multirow{2}{*}{ 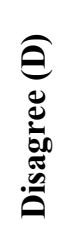 } & \multirow{2}{*}{ 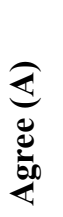 } & \multirow{2}{*}{ 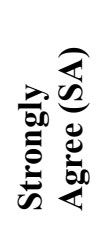 } \\
\hline Attitude towards Entrepreneurship & & & & \\
\hline 1. I have always worked hard in order to be among the best in my field. & & & & \\
\hline 2. Concrete results are necessary in order to judge business success. & & & & \\
\hline $\begin{array}{l}\text { 3. I spend a considerable amount of time making the organization I belong } \\
\text { to function better. }\end{array}$ & & & & \\
\hline $\begin{array}{l}\text { 4. Motivation I have in business is due mainly to my expertise in certain } \\
\text { areas. }\end{array}$ & & & & \\
\hline $\begin{array}{l}\text { 5. I often sacrifice personal comfort in order to take advantage of business } \\
\text { opportunities. }\end{array}$ & & & & \\
\hline 6. I get my biggest thrills when my work is among the best. & & & & \\
\hline $\begin{array}{l}\text { 7. I feel energetic working with innovative colleagues in dynamic business } \\
\text { climates. }\end{array}$ & & & & \\
\hline
\end{tabular}




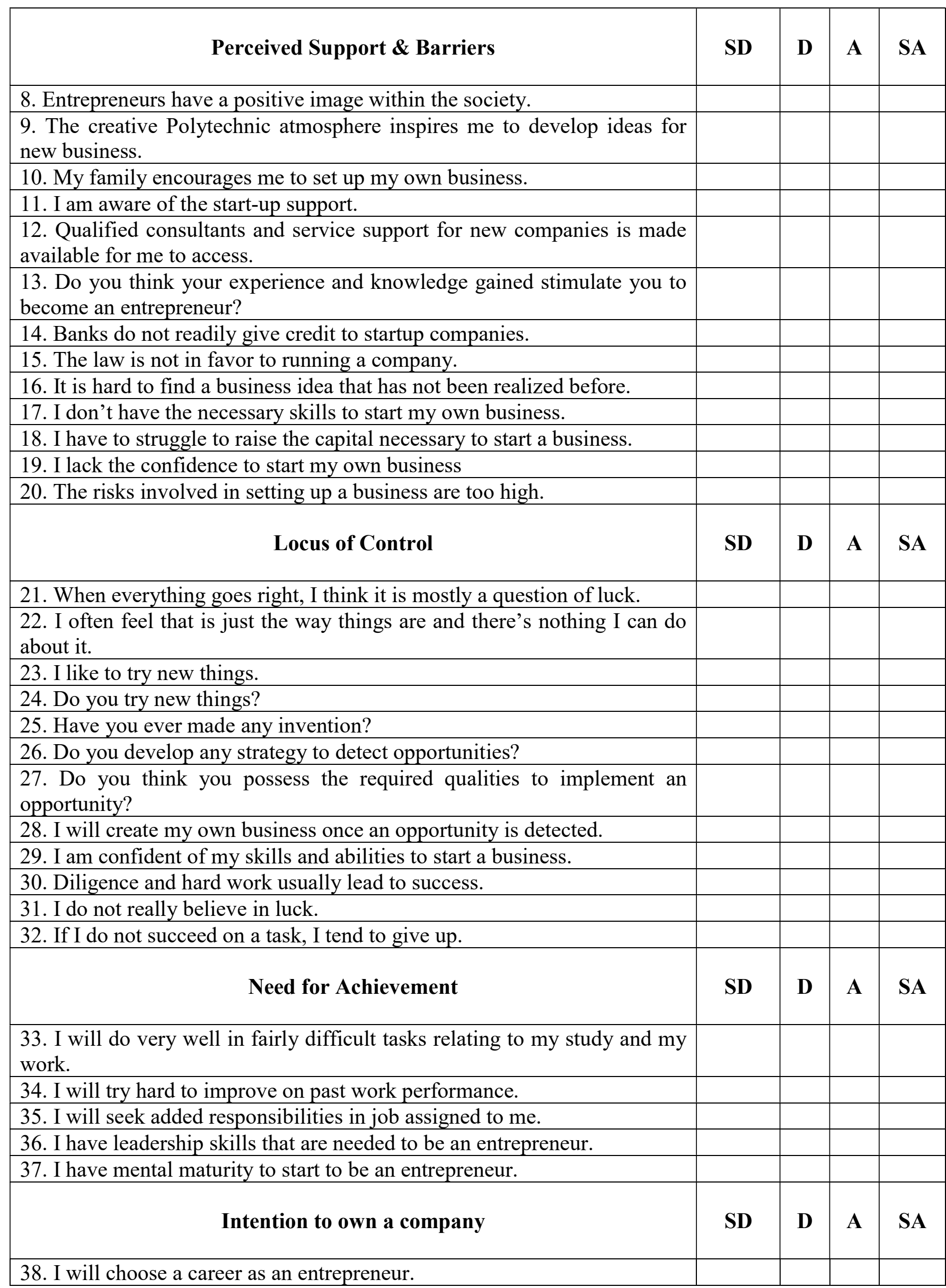


39. I will choose a career as an employee in a company/an organization. 40. I prefer to be an entrepreneur rather than to be an employee in a company/an organization.

41. The idea of starting your own business is appealing.

42. I would rather found/form a company than to be a manager of an existing one.

43. I want the freedom to express myself in my own business.

44. I would rather be my own boss than have a secure job

45. I relish the challenge of creating a new business.

46. You can only make big money if you are self-employed.

\begin{tabular}{|c|c|c|c|c|}
\hline Instrumental Readiness & SD & D & $\mathbf{A}$ & SA \\
\hline \multicolumn{5}{|l|}{ 47. I have access to capital to start up as an entrepreneur. } \\
\hline \multicolumn{5}{|l|}{$\begin{array}{l}\text { 48. I have good social networks that can be utilized when I decide to be an } \\
\text { entrepreneur. }\end{array}$} \\
\hline \multicolumn{5}{|l|}{ 49. I have access to supporting information to start to be an entrepreneur. } \\
\hline Subjective Norms & SD & D & $\mathbf{A}$ & SA \\
\hline \multicolumn{5}{|l|}{$\begin{array}{l}\text { 50. My closest family thinks that I should pursue a career as an } \\
\text { entrepreneur. }\end{array}$} \\
\hline \multicolumn{5}{|l|}{$\begin{array}{l}\text { 51. My closest friends think that I should pursue a career as an } \\
\text { entrepreneur. }\end{array}$} \\
\hline $\begin{array}{l}\text { 52. People who are important to me think that I should pursue a career as } \\
\text { an entrepreneur. }\end{array}$ & & & & \\
\hline
\end{tabular}

